\title{
EKSISTENSI PERJANJIAN ELEKTRONIK SEBAGAI ALAT BUKTI DALAM HUKUM
}

\author{
ACARA PERDATA
}

\section{Leonard Parulian}

Universitas Borneo tarakan

\begin{abstract}
One form of the Industrial Revolution 4.0 that we can recognize in everyday life is electronic commerce, namely the use of communication networks and computers to carry out business processes that are agreed upon and carried out by the parties and set forth in electronic agreements/contracts. The electronic agreement/contract is carried out on the basis of trust obtained by providing legal recognition of electronic written form in the form of an electronic signature. If there is a broken promise/default by one of the parties entering into an electronic agreement/contract with electronic document evidence signed with electronic signature as evidence, then it must be known carefully the strength of the evidence of electronic agreement on the electronic document and the method of settling the civil dispute.

This study aimed to examine and analyze the strength of the evidence of electronic agreements on authentic deeds and patterns of settlement of civil case disputes submitted by the parties with evidence in the form of electronic agreements. The study used a normative juridical method with legal and conceptual approaches and primary and secondary sources of legal material.

From the results of the study it can be concluded that the strength of proof of electronic documents signed with electronic signatures is contrary to the strength of proof of authentic deeds made by or in front of public officials in charge where the deed was made or by the authorized public official. In addition, related to the recognition of electronic documents in the judicial system, there is a void in procedural law because it does not regulate electronic documents as evidence but rather electronic documents in the form of decisions or indictments as appeals for cassation requests and reconsideration.
\end{abstract}

Keywords: Electronic Agreement, Electronic Signature, Authentic Deed, Evidence

\section{PENDAHULUAN}

Indonesia memasuki era pemanfaatan teknologi informasi untuk kepentingan ekonomi skala besar. Hal ini ditegaskan melalui pidato kenegaraan Presiden Republik Indonesia Joko Widodo dalam rangka Hari Ulang Tahun ke tujuh puluh tiga Proklamasi Kemerdekaan Republik Indonesia di Gedung Parlemen, Jakarta. ${ }^{48}$ Dalam pidato tersebut

48

https://www.cnbcindonesia.com/news/20180816114214-4-28906/revolusi-industri40-jokowi-indonesia-harus-beradaptasi, tanggal kunjung 29 Juli 2019, (14.00). 
Presiden menegaskan bahwa Negara Indonesia harus siap dan mulai berbicara tentang Artificial Intelligence, Internet of Things, dan berbagai kemajuan teknologi yang hampir setiap detik selalu berubah dan muncul yang baru. Revolusi Industri 4.0 itu sendiri berkembang di era 2000'an hingga saat ini yang merupakan era penerapan teknologi modern, antara lain teknologi fiber (fiber technology) dan sistem jaringan terintegrasi (integrated network), yang bekerja di setiap aktivitas ekonomi dari produksi hingga konsumsi. Kagerman berpendapat bahwa manfaat dari Industri 4.0 ini adalah mampu memenuhi kebutuhan pelanggan secara individu, proses rekayasa dan bisnis menjadi dinamis, pengambilan keputusan menjadi lebih optimal, melahirkan model bisnis baru dan cara baru dalam mengkreasi nilai tambah. Dengan manfaat yang ada, secara umum ada lima tantangan besar yang akan dihadapi yaitu aspek pengetahuan, teknologi, ekonomi, sosial, dan politik (hukum). Guna menjawab tantangan tersebut, diperlukan usaha yang besar, terencana dan strategis baik dari sisi regulator (Pemerintah), kalangan akademisi maupun praktisi.

Pada tahun 1996, The United Nations Commission on International Trade Law (UNCITRAL) mengeluarkan Model Law on Electronic Commerce 1996 dan pada tahun 2001 mengeluarkan Model Law on Electronic signature 2001. Dilihat dari bentuknya peraturan-peraturan secara internasional ini menandakan bahwa masyarakat internasional sangat membutuhkan peraturan yang sesuai dengan perkembangan teknologi terutama di bidang transaksi-transaksi perdagangan internasional. Perkembangan perdagangan internasional tidak dapat terlepas dari pengaruh perkembangan teknologi. Pengaruh tersebut dewasa ini semakin nyata dengan lahirnya e-commerce seperti yang telah dipaparkan diatas. UNCITRAL Model Law ini dibentuk sebagai aturan dasar untuk mengatur keabsahan, pengakuan, dan akibat dari pesanpesan elektronik (electronic messaging) yang didasarkan pada penggunaan komputer

\footnotetext{
${ }^{49}$ http://www.vdinachrichten.com/Technik-Gesselschaft/Industrie-40-Mit-Internet-DingeWeg-4-industriellen-Revolution, tanggal kunjung 29 juli 2019, (15.00).

Zhou, K., Taigang $\downarrow$, dan Lifeng, Z., Industry 4.0: Towards future industrial opportunities and challenges, 12 International Conference on Fuzzy System, USA, 2015, h. 1.
} 
pada perdagangan.

Setiap orang dapat memberikan dan mendapatkan informasi tentang segala hal, termasuk juga informasi terhadap penjualan suatu barang atau jasa dengan menggunakan teknologi informasi ini, dari informasi tersebut, apabila seseorang tersebut tertarik untuk memiliki sesuatu yang ditawarkan maka akan terjadi suatu transaksi elektronik. Kedudukan sederajat antara perlindungan hukum, kehandalan, dan keamanan teknologi informasi akan menciptakan suatu kepercayaan kepada penggunanya, tanpa kepercayaan ini transaksi elektronik maupun perdagangan elektronik tidak akan berkembang. Kepercayaan itu dapat diperoleh dengan memberikan pengakuan hukum terhadap tulisan berbentuk elektronik. Tanda tangan digital (Digital Signature) adalah suatu tanda tangan yang dibuat secara elektronik yang berfungsi sama dengan tanda tangan biasa pada dokumen kertas biasa. Tanda tangan adalah data yang apabila tidak dipalsukan dapat berfungsi untuk membenarkan perbuatan orang yang namanya tertera pada suatu dokumen yang ditandatanganinya itu. Dalam arti lain pengakuan tanda tangan dalam ranah hukum bahwa suatu akta baru dapat dikatakan sebagai akta otentik jika suatu tulisan itu memang sengaja dibuat untuk dijadikan bukti tentang suatu peristiwa yang ditandatangani.

Berbeda dengan transaksi dalam dunia nyata yang mempergunakan kertas atau paper based transaction. Setiap surat atau dokumen yang diterbitkan para pihak atau masingmasing pihak ditandatangani dengan tulisan tangan sendiri oleh yang bersangkutan sesuai dengan ketentuan Pasal 1874 KUHPerdata. Dalam paper based contract, tidak sulit mengindetifikasi identitas penanda tangan, sehingga tidak menimbulkan permasalahan yang rumit dalam menilai kebenaran tanda tangan yang tercantum pada dokumen yang bersangkutan. ${ }^{53}$ Tidak demikian halnya dalam transaksi dunia maya melalui internet. Tanda tangan yang tercantum berbentuk Digital Signature atau 51

Huala Adolf, Hukum Perdagangan Internasional, Raja Grafindo Persada, Jakarta, 2006, h. 168.

Sudikno Mertokusumo, Hukum Acara Perdata Indonesia, Cahaya Atma Pustaka, Yogyakarta, 2013, h. 28.

M Yahya Harahap, Hukum Acara Perdata Tentang Gugatan, Persidangan, Penyitaan, Pembuktian, dan Putusan Pengadilan, Sinar Grafika, Jakarta, 2017, h. 637. 
electronic signature. Yang dimaksud dengan tanda tangan ini, bukan digitized image of handwritten atau bukan tanda tangan atau gambar, tetapi adalah dengan jalan terlebih dahulu menciptakan suatu message digest atau hash, berupa dokumen mathematical summary yang akan dikirimkan melalui cyber space.

Pada tahun 2008, diterbitkan Undang-Undang Nomor 11 Tahun 2008 tentang Informasi dan Transaksi Elektronik (selanjutnya disebut sebagai UU ITE). Berdasarkan pada Pasal 18 jo. Pasal 7 jo. Pasal 11 UU ITE tersebut maka kekuatan pembuktian dokumen elektronik tersebut yang ditandatangani dengan Digital Signature sama dengan kekuatan pembuktian akta otentik yang dibuat oleh pejabat umum yang berwenang. Dipertegas lagi melalui Peraturan Pemerintah Republik Indonesia Nomor 82 Tahun 2012 tentang Penyelenggaraan Sistem dan Transaksi Elektronik (PP PSTE). Aturan tersebut di atas bertentangan dengan Pasal 1 ayat (7) Undang-Undang Nomor 30 Tahun 2004 tentang Jabatan Notaris (UU Jabatan Notaris) yang menyatakan bahwa Akta Notaris adalah akta otentik yang dibuat oleh atau dihadapan Notaris menurut bentuk dan tata cara yang ditetapkan dalam Undang-Undang ini sedangkan pengertian akta otentik berdasarkan Pasal 1868 KUHPerdata menyatakan bahwa suatu akta yang didalam bentuk yang ditentukan oleh Undang-Undang, dibuat oleh atau dihadapan pegawai-pegawai umum yang berkuasa untuk itu di tempat dimana akta dibuatnya.

Akibat terjadi suatu pertentangan aturan tersebut, maka apabila salah satu pihak mengajukan gugatan dengan alat bukti dokumen elektronik yang ditandatangani dengan tanda tangan elektronik sebagal alat bukti, maka didalam menyelesaikan sengketa di Pengadilan, Hakim dituntut untuk berani melakukan terobosan hukum, karena dia yang paling berkuasa dalam memutuskan suatu perkara dan area Hakim juga yang dapat memberi suatu vonnis van de rechter, yang tidak langsung dapat didasarkan atas suatu peraturan hukum tertulis atau tidak tertulis.

Pengakuan Mahkamah Agung terhadap dokumen elektronik pada sistem peradilan pertama kali diketahui melalui Surat Edaran Mahkamah Agung (SEMA) Nomor 14 Tahun 2010 tentang Dokumen Elektronik sebagai Kelengkapan Permohonan Kasasi

Ibid.

78 | Universitas Borneo Tarakan 
dan Peninjauan Kembali. SEMA ini bertujuan untuk meningkatkan efisiensi dan efektivitas proses minutasi berkas perkara serta menunjang pelaksanaan transparansi dan akuntabilitas serta pelayanan publik pada Mahkamah Agung dan Badan Peradilan di bawahnya. Namun SEMA ini tidaklah mengatur tentang dokumen elektronik sebagai alat bukti melainkan dokumen elektronik berupa putusan maupun dakwaan yang dimasukkan pada compact disc, flash disc dikirim melalui email sebagai kelengkapan permohonan kasasi dan peninjauan kembali.

SEMA ini telah mengalami perubahan berdasarkan SEMA 1 Tahun 2014 tentang Perubahan atas SEMA 14 Tahun 2010 tentang Dokumen Elektronik sebagai kelengkapan Permohonan Kasasi dan Peninjauan Kembali. Perubahan SEMA ini dilakukan berkaitan dengan sistem pemeriksaan berkas dari sistem bergiliran menjadi sistem baca bersama yang diarahkan secara elektronik. Dalam butir-butir SEMA terdapat penambahan detail dokumen-dokumen yang wajib diserahkan para pihak berperkara secara elektronik tapi sekali lagi kepentingannya bukan dalam kaitannya sebagai alat bukti elektronik. Perbedaan lainnya dengan SEMA yang lama ialah cara penyertaan dokumen melalui fitur komunikasi data (menu upaya hukum) pada direktori putusan Mahkamah Agung karena cara lama melalui compact disc dan pengiriman $e$ document memiliki sejumlah kendala diantaranya data tidak terbaca, perangkat penyimpan data hilang dan lain-lain. Simpulan singkatnya, SEMA tersebut mengakui dokumen elektronik untuk kelengkapan Permohonan Kasasi dan Peninjauan Kembali, bukan untuk alat bukti persidangan dan penyerahan dokumen oleh pengadilan tingkat pertama dilakukan melalui fitur komunikasi data dan tidak melalui perangkat flash disc atau compact disc kecuali dalam keadaan khusus.

Disinilah terdapat kekosongan hukum acara, karena kalau dalam praktiknya ada yang menyerahkan melalui compact disc atau flash disc maka sesuai SEMA 1/2014 dijelaskan bahwa hal tersebut menyebabkan sejumlah kendala namun apabila dikirim melalui e-document juga belum diatur tata cara pengirimannya. Tata cara penyerahan 55

https://www.mahkamahagung.go.id/id/artikel/3048/eksistensi-dokumen-elektronik-di 5persidangan-perdata, tanggal kunjung 31 Juli 2019, (16.00).

Ibid. 
menjadi penting karena menyangkut sah atau tidaknya Hukum Acara Perdata yang diterapkan dan dalam rangka memenuhi unsur dijamin keutuhannya pada Pasal 6 UU ITE. Dijamin keutuhannya berarti tidak diubah-ubah bentuknya sejak dari dokumen elektronik tersebut disahkan. Dalam hal dokumen elektronik telah diserahkan di persidangan menurut ketentuan Pasal 137 HIR mengatur bahwa Pihak-pihak dapat menuntut melihat surat-surat keterangan lawannya dan sebaliknya, surat mana diserahkan kepada Hakim buat keperluan itu. Dalam menjaga asas keterbukaan pembuktian dipersidangan maka ketentuan 137 HIR juga harus dapat diterapkan pada dokumen elektronik ketika pihak lawan meminta untuk diperlihatkan. Untuk itu, diperlukan perangkat teknologi berupa laptop maupun proyektor agar dapat menampilkan atau memperlihatkan dokumen elektronik dan inipun tidak diatur.

Tanda tangan digital sebenarnya dapat memberikan jaminan terhadap keamanan dokumen dibandingkan dengan tanda tangan biasa. Penerima pesan elektronik yang dibubuhi tanda tangan digital dapat memeriksa apakah pesan tersebut benar-benar datang dari pengirim yang benar dan apakah pesan itu telah diubah setelah ditandatangani baik secara sengaja atau tidak sengaja dalam hal sistem pembayaran elektronik, alat bukti lain yang dapat digunakan selain data elektronik atau digital berupa Digital Signature untuk dapat diklasifikasikan. Hanya saja, apakah hukum acara yang berlaku di Pengadilan telah mengatur hal ini? dan bagaimana eksistensi tanda tangan elektronik selama ini di Indonesia?

\section{A. Permasalahan}

Permasalahan yang dibahas dalam tulisan ini adalah kekuatan pembuktian perjanjian elektronik pada akta otentik dan penyelesaian sengketa perkara perdata yang diajukan para pihak dengan alat bukti perjanjian elektronik.

${ }_{58}^{57}$ Ibid.

Abdul Halim Barkatullah dan Teguh Prasetyo, Bisnis E-Commerce, Pustaka Pelajar, Yogyakarta, 2005, h. 110. 


\section{B. Pembahasan}

\section{Konsep Perjanjian dan Perjanjian Elektronik}

Istilah perjanjian merupakan terjemahan dari kata overeenkomst (Belanda) atau contract (Inggris), ada dua macam teori yang membahas tentang pengertian perjanjian, yaitu teori lama dan teori baru. Menurut teori lama, yang disebut perjanjian adalah perbuatan hukum berdasarkan kata sepakat untuk menimbulkan akibat hukum. Lalu, menurut teori baru yang dikemukakan oleh Van antara dua pihak atau lebih berdasarkan kata sepakat untuk menimbulkan akibat hukum.

Menurut R. Subekti yang dimaksud dengan perjanjian adalah suatu peristiwa dimana sesorang berjanji kepada orang lain atau dimana dua orang itu saling berjanji melaksanakan suatu hal. ${ }^{60}$ Menurut Wirjono Prodjodikoro, yang dimaksud dengan perjanjian adalah suatu perhubungan hukum mengenai harta benda antara dua pihak, dengan mana satu pihak berjanji atau dianggap berjanji untuk melakukan sesuatu hal, sedang pihak lain berhak menuntut pelaksanaan janji itu.

Menurut Pasal 1313 KUHPerdata menyebutkan bahwa : "Perjanjian adalah suatu perbuatan dengan mana satu orang atau lebih mengikatkan dirinya kepada satu orang atau lebih lainnya". Perjanjian dalam arti sempit adalah suatu persetujuan dengan mana dua pihak atau lebih saling mengikatkan diri untuk melaksanakan suatu hal yang bersifat kebendaan dibidang harta kekayaan. ${ }^{61}$ Pasal 1313 KUHPerdata mengatur bahwa : "Perjanjian adalah suatu perbuatan dengan mana satu orang atau lebih mengikatkan dirinya terhadap satu orang atau lebih lainnya"

Dalam UU ITE, pengertian perjanjian/kontrak elektronik hanya diberikan batasan secara umum. Perjanjian/kontrak elektronik menurut Pasal 1 angka 17 UU ITE didefinisikan sebagai perjanjian para pihak yang dibuat melalui Sistem Elektronik. 59

Salim HS, Hukum Kontrak: Teori dan Teknik Penyusunan Kontrak, Sinar Grafika, Jokarta, h. 61.

${ }_{61}$ Subekti, Aneka Perjanjian, Intermasa, Bandung, 1995, h. 1.

Abdulkadir Muhammad, 2010, Hukum Perdata Indonesia, Bandung, Citra Aditya Bakti, h. 290. 
Sedangkan yang dimaksud dengan Sistem Elektronik adalah serangkaian perangkat dan prosedur elektronik yang berfungsi mempersiapkan, mengumpulkan, mengolah, menganalisis, menyimpan, menampilkan, mengumumkan, mengirimkan, dan/atau menyebarkan Informasi Elektronik. Informasi Elektronik sebagaimana dimaksud diatas adalah satu atau sekumpulan data elektronik, termasuk tetapi tidak terbatas pada tulisan, suara, gambar, peta, rancangan, foto, electronic data interchange (EDI), surat elektronik (electronic mai), telegram, teleks, telecopy atau sejenisnya, huruf, tanda, angka, kode akses, simbol, atau perforasi yang telah diolah yang memiliki arti atau dapat dipahami oleh orang yang mampu memahaminya.

Terkait dengan keabsahan perjanjian/kontrak elektronik itu sendiri, dalam UU ITE hanya dirumuskan secara implisit. Pasal 18 ayat (1) UU ITE menyatakan bahwa Transaksi Elektronik yang dituangkan ke dalam Kontrak Elektronik mengikat para pihak. Bilamana dianalisis, rumusan pasal ini merujuk pada argumen bahwa perjanjian/kontrak elektronik mengikat para pihak yang membuatnya sebagaimana layaknya sebuah undang-undang bilamana transaksi elektronik yang mendahului lahirnya suatu perjanjian/kontrak elektronik tersebut dibuat secara sah (menurut hukum) dan telah dipenuhinya syarat sahnya suatu perjanjian sebagaimana yang dikenal dalam KUHPerdata.

Menurut Julian Ding, electronic commerce transaction adalah transaksi dagang antara penjual dengan pembeli guna penyediaan barang dan jasa. Kontrak ini dilakukan dengan media elektronik (digital medium) di mana para pihak tidak hadir secara fisik. Medium ini terdapat di dalam jaringan umum dengan sistem terbuka yaitu internet atau World Wide Web. Transaksi ini terjadi terlepas dari batas wilayah dan syarat nasional. ${ }^{62}$ Di lain sisi Black's Law Dictionary mengertikan e-commerce sebagai the practice of buying and selling goods and services on the internet. The shortened form of electronic, has become a popular prefix for other terms associated with electronic transaction. Menurut pengertian dari Black's Law Dictionary bahwa e-commerce adalah praktek jual

\footnotetext{
62 Julian Ding, E-Commerce: Law \& Practice, Malaysia: Sweet \& Maxwell, Asia, 1999, h. 25.
}

82 | Universitas Borneo Tarakan 
beli barang dan/atau jasa dengan menggunakan internet. Berdasarkan definisi di atas dapat disimpulkan bahwa e-commerce merupakan segala kegiatan bisnis yang menyangkut konsumen (consumer), manufaktur (manufacture), service provider, dan pedagang perantara (intermediaries) dengan menggunakan media elektronik.

\section{Otentifikasi Perjanjian/Kontrak Elektronik}

Keautentikan dan integritas data message dan tanda tangan elektronik sangat penting dalam e-contract, karena data message inilah yang menjadi landasan utama terbentuknya suatu e-contract, baik dalam hubungannya dengan kesepakatan mengenai persyaratan-persyaratan dan ketentuan-ketentuan kontrak (term and conditions) ataupun yang berkaitan dengan substansi kontrak itu sendiri. Sejauh ini telah ada beberapa teknik yang ditawarkan dan dianggap cukup mampu untuk memberikan jaminan bagi keautentikan dan integritas suatu data message. Teknik yang dimaksud adalah teknik kriptografi (cryptography) dan tanda tangan elektronik (electronic signature). Kedua teknik tersebut selama ini dianggap sebagai pilar atau penopang perkembangan e-commerce dan sekaligus dianggap telah memungkinkan dokumen elektronik untuk memiliki posisi yang sama dengan dokumen-dokumen berbasis kertas.

Dalam rangka pembuatan suatu perjanjian atau transaksi elektronik yang dituangkan dalam bentuk dokumen elektronik, maka keabsahan suatu dokumen elektronik tersebut di dalamnya juga harus memuat sebuah tanda-tangan dalam bentuk elektronik, hal ini sesuai dengan pengaturan tentang unsur-unsur terpenting dalam pembuatan akte, yang diatur di dalam Pasal 1867 BW jo. Pasal 1874 BW, dan syarat sahnya perjanjian yang diatur di dalam Pasal 1320 BW. Selanjutnya, ditentukan bahwa sebuah Tanda Tangan Elektronik memiliki kekuatan hukum dan akibat hukum yang sah selama memenuhi persyaratan sebagaimana ditentukan dalam Pasal 11 UU ITE, yaitu :

a. Data pembuatan tanda tangan elektronik terkait hanya kepada para penanda tangan;

63

Ibid. 
b. Data pada pembuatan tanda tangan elektronik pada saat proses penandatanganan elektronik hanya berada dalam kuasa penanda tangan;

c. Segala perubahan terhadap tanda tangan elektronik yang terjadi setelah waktu penandatanganan dapat diketahui;

d. Segala perubahan terhadap Informasi Elektronik yang terkait dengan tanda tangan elektronik tersetbu setelah waktu penandatanganan dapat diketahui;

e. Terdapat cara tertentu yang dipakai untuk mengidentifikasi siapa penandatangannya; dan

f. Terdapat cara tertentu untuk menunjukkan bahwa penanda tangan telah memberikan suatu persetujuan terhadap informasi elektronik yang terkait.

\section{Tinjauan Hukum Acara Perdata}

Setiap orang tidak boleh bertindak semaunya dan main hakim sendiri untuk mempertahankan hak dan kewajiban seperti yang telah diatur dalam hukum perdata, melainkan harus berdasarkan apa yang sudah diatur dan ditetapkan dalam undangundang. Apabila pihak yang bersangkutan tidak dapat menyelesaikan masalah secara damai, pihak tersebut dapat meminta bantuan kepada hakim lewat pengadilan. Penyelesaian dengan cara tersebut diatur dalam Hukum Acara Perdata.

Hukum Acara Perdata digunakan untuk menjamin terlaksananya Hukum Perdata. Hukum Acara Perdata lebih melaksanakan dan mempertahankan atau menegakan kaidah hukum perdata yang ada atau melindungi hak perseorangan, hal ini berbeda dengan hukum perdata yang lebih mengatur tentang hak dan kewajiban seseorang terhadap yang lain. Menurut Sudikno Mertokosumo, Hukum Acara Perdata adalah : "Peraturan hukum yang mengatur bagaimana caranya menjamin ditaatinya hukum perdata materiil dengan perantara hakim. Dengan perkataan lain hukum acara perdata adalah peraturan hukum yang menentukan bagaimana caranya menjamin pelaksanaan hukum perdata materiil. Lebih konkrit lagi dapatlah dikatakan bahwa Hukum Acara Perdata mengatur tentang bagaimana caranya mengajukan tuntutan hak, memeriksa, 
memutusnya dan pelaksanaannya dari pada putusannya. Tuntutan dalam hal ini tidak lain adalah tindakan yang bertujuan memperoleh perlindungan hukum yang diberikan oleh pengadilan untuk mencegah 'eigenrichting' atau tindakan menghakimi sendiri. Tindakan menghakimi sendiri merupakan tindakan untuk melaksanakan hak menurut kehendaknya sendiri yang bersifat sewenang-wenang, tanpa persetujuan dari pihak lain yang berkepentingan, sehingga akan menimbulkan kerugian. Oleh karena itu tindakan menghakimi sendiri itu tidak dibenarkan dalam hal kita hendak memperjuangkan atau melaksanakan hak kita."

Sumber Hukum Acara Perdata dalam praktik peradilan adalah sebagai berikut :

a. HIR (Het Herziene Indonesia Reglement) diperbaharui S.1848 No.16, S.1941 No.44. HIR sering di terjemahkan menjadi "Reglemen Indonesia yang diperbaharui”, yaitu hukum acara dalam persidangan perkara perdara maupun pidana yang berlaku di pulau Jawa dan Madura. Reglemen ini berlaku di jaman Hindia Belanda, tercantum di Berita Negara (Staatblad) Nomor16 Tahun 1848. Bab IX dalam HIR mengatur Hukum Acara Perdata yaitu tentang "Perihal Mengadili Perkara dalam Perkara Perdata yang diperiksa Oleh Pengadilan Negeri"

b. RBg (Rechtsreglement voor de Buitengewesten), S. 1927 No.227). RBg sering diterjemahkan Reglemen Hukum Daerah Seberang (diluar Jawa Madura), yaitu hukum acara yang berlaku di persidangan perkara perdata maupun pidana di pengadilan di luar Jawa dan Madura. Ketentun hukum acara perdata terdapat dalam Bab II yang terdiri dari tujuh title dan Pasal 104 sampai Pasal 323, hanya title IV dan V yang berlaku sampai sekarang bagi Landraad (Pengadilan Negeri).

c. Kitab Undang Undang Hukum Acara Perdata (Burgerlijk Wetboek). KUHPerdata sebenarnya merupakan suatu aturan hukum yang dibuat oleh pemerintah Hindia Belanda yang ditujukan bagi kaum golongan warga negara bukan asli Eropa, Tionghoa dan juga Timur asing. Namun berdasarkan Pasal 2 aturan peralihan UUD 1945, seluruh peraturan Hindia-Belanda berlaku bagi warga negara Indonesia (asas konkordasi). Beberapa ketentuan dari BW pada saat ini diatur secara terpisah atau tersendiri oleh beberapa peraturan perundang-undangan. Walaupun KUHPerdata 
merupakan kodifikasi dari hukum perdata materiil, namun juga memuat hukum acara perdata terutama dalam buku IV tentang pembuktian dan daluwarsa (Pasal 1865-1993). Selain itu juga terdapat dalam beberapa Pasal Buku I misalnya tentang tempat tinggal atau domisili (Pasal 17-25), serta Buku II dan III (Pasal 533, 535, 1244, 1365). Selain itu Hukum Acara Perdata juga diatur dalam Undang-Undang Kepailitan Staatblad 1906 No.348 dan Reglemen tentang Organisasi Kehakiman Staatblad (Reglement op de Rechtsterlijke Orgnisatie in het beleid der Justitie in Indonesia) 1847 No.23 yang merupakan sumber dasar penerapan dalam hukum acara perdata di Pengadilan.

d. Surat Edaran Mahkamah Agung Nomor 7 Tahun 2001 tentang Pemeriksaan Setempat. Pemeriksaan setempat adalah metode hakim untuk mengetahui secara jelas dan tepat mengenai keberadaan objek sengketa gugatan sebelum Majelis Hakim membacakan putusan.

e. Yurisprudensi merupakan sumber pula dalam hukum acara perdata.

\section{Pembuktian Perjanjian Elektronik}

Pembuktian adalah penyajian alat-alat bukti yang sah menurut hukum oleh para pihak yang beperkara kepada hakim dalam suatu persidangan, dengan tujuan untuk memperkuat kebenaran dalil tentang fakta hukum yang menjadi pokok sengketa, sehingga hakim memperoleh dasar kepastian untuk menjatuhkan keputusan. ${ }^{64}$ Menurut M. Yahya Harahap, pembuktian adalah kemampuan Penggugat atau Tergugat memanfaatkan hukum pembuktian untuk mendukung dan membenarkan hubungan hukum dan peristiwa-peristiwa yang didalilkan atau dibantahkan dalam hubungan hukum yang diperkarakan. Subekti berpendapat bahwa pembuktian adalah suatu proses bagaimana alat-alat bukti dipergunakan, diajukan atau dipertahankan sesuai

\footnotetext{
64

Bahtiar Effendi, Masdari Tasmin, dan A Chodari, Surat Gugat dan Hukum Pembuktian
} Dalam Perkara Perdata, Citra Aditya Bakti, Bandung, 1999, h. 50. 
hukum acara yang berlaku.

Transaksi e-commerce menimbulkan bukti elektronik yang dapat berupa informasi elektronik atau dokumen elektronik. Proses pertukaran informasi melalui perangkat elektronik (e-mail) berupa penawaran dari penjual dan penerimaan dari pembeli, menimbulkan tercapainya suatu kesepakatan (salah satu syarat dalam perikatan sebagaimana diatur dalam Pasal 1320 KUHPerdata) melalui media elektronik, sedangkan persetujuan merupakan salah satu sumber terjadinya perikatan. Berdasarkan ketentuan pada Pasal 1 angka 2 UU ITE, yang dimaksud dengan transaksi elektronik adalah suatu perbuatan hukum yang dilakukan dan menggunakan komputer dan/atau media elektronik lainnya. Dalam rangka melakukan transaksi elektronik tersebut, maka para pihak akan selalu menggunakan suatu dokumen elektronik sebagai landasan bagi mereka untuk melakukan hubungan hukum.

\section{a. Sistem Pembuktian}

1) Sistem pembuktian yang menyandarkan diri pada alat bukti saja, yang ditentukan oleh Undang-undang;

2) Suatu gugat dikabulkan hanya didasarkan pada alat-alat bukti yang sah, keyakinan hakim diabaikan;

3) Pada pokoknya suatu gugatan yang sudah memenuhi cara-cara pembuktian dan alat bukti yang sah, gugatan harus dikabulkan;

4) Hakim laksana robot yang menjalankan UU, namun ada baiknya system pembuktian ini, yakni hakim akan berusaha membuktikan dalil-dalil gugatan atau jawaban tanpa dipengaruhi oleh nuraninya, sehingga benar-benar objektif, yaitu menurut Undangundang;

5) Dalam sistem pembuktian positif yang dicari kebenaran formil.

\footnotetext{
65

${ }_{66}^{65}$ Subekti, Hukum Pembuktian, Balai Pustaka, Jakarta, 2015, h. 7.

R Setiawan, Pokok-Pokok Hukum Perikatan, Bina Cipta, Bandung, 1999, h. 13.
} 


\section{b. Alat Bukti Dalam Perkara Perdata}

Alat bukti adalah segala sesuatu yang oleh undang-undang ditetapkan dapat dipakai membuktikan sesuatu. Alat bukti disampaikan dalam persidangan pemeriksaan perkara dalam tahap pembuktian. Pembuktian adalah upaya yang dilakukan para pihak dalam berperkara untuk menguatkan dan membuktikan dalil-dalil yang diajukan agar dapat meyakinkan hakim yang memeriksa perkara. Yang harus dibuktikan dalam sidang adalah segala sesuatu yang didalilkan disangkal atau dibantah oleh pihak lawan. Yang tidak perlu dibuktikan adalah segala sesuatu yang diakui, dibenarkan, tidak dibantah pihak lawan, segala sesuatu yang dilihat oleh hakim, dan segala sesuatu yang merupakan kebenaran yang bersifat umum.

Alat bukti yang sah dan dapat dipergunakan untuk pembuktian adalah sebagai berikut :

1) Bukti surat

2) Bukti saksi

3) Persangkaan

4) Pengakuan

5) Sumpah

\section{Konsep Penyelesaian Sengketa}

Penyelesaian sengketa menurut ketentuan peraturan perundang-undangan di Indonesia mengatur terdapat 2 (dua) jalur penyelesaian. Jalur tersebut antara lain jalur penyelesaian melalui proses litigasi dan proses non litigasi. Penyelesaian sengketa yang dilakukan melalui proses litigasi tunduk pada undang-undang yang mengatur tentang lembaga peradilan. Penyelesaian sengketa yang dilakukan di lembaga diluar badan peradilan yang berebntuk non litigasi, maka harus tunduk pada undang-undang

${ }^{67}$ Dewi Nurul Mustjtari, Penyelesaian Sengketa dalam Praktik Perbankan Syariah, Parama Publishing, Yogyakarta, 2012, h. 220. 
yang mengatur tentang arbitrase dan alternatif penyelesaina sengketa. ${ }^{68}$ Non litigasi merupakan sistem penyelesaian sengketa tanpa melalui lembaga yudisial (peradilan) atau dikenal dengan arbitrase dan alternatif penyelesaian sengketa.

\section{Tanda Tangan Elektronik}

Di dalam badan peradilan di Indonesia, dikenal suatu hukum acara yang fungsinya mengatur hal-hal yang diselenggarakan di dalam proses peradilan. Di dalam hal ini, hukum positif (hukum yang berlaku saat ini) yang ada adalah HIR (Herzien Inlands Reglement) atau yang dikenal dengan sebutan RIB (Reglemen Indonesia yang diperBaharui), yaitu undang-undang yang termuat dalam Staatsblaad 1941 No.44. Mungkin terpikir oleh awam, inilah yang sering didengungkan oleh para ahli hukum di Indonesia, mengenai produk hukum Belanda yang masih berlaku sampai sekarang ini. Hal ini benar adanya, sebagaimana adanya kekosongan hukum dan keberlakuan dari HIR ini, juga hanya diatur dalam UU Darurat. Kenyataan inilah yang harus kita hadapi bersama, mengingat sebagai produk lama maka besar pula kemungkinan dimana kita hanya menemui peraturan hukum yang mengatur mengenai hal-hal yang sifatnya tidak atau belum up to date, apalagi dalam hal ini kita membicarakan mengenai kegiatan sehubungan dengan e-commerce dengan penggunaan Digital Signature, sesuatu yang baru dan belum terpikirkan oleh pembentuk undang-undang ini pada waktu dibuatnya.

Pengakuan dokumen yang telah ditandatangani dengan menggunakan Digital Signature, setelah dikeluarkan Undang-Undang Nomor 11 Tahun 2008 tentang Informasi Dan Transaksi Elektronik, maka pengakuan dokumen elektronik yang ditandatangani dengan tanda tangan Digital Signature tersebut, merupakan perluasan dari pembuktian hukum acara perdata di Indonesia, sehingga seluruh transaksi elektronik dengan tanda tangan elektronik dapat dianggap sebagai akta, bahkan kekuatan pembuktiannya sama dengan akta otentik yang dibuat oleh pejabat yang berwenang. Kecuali yang ditentukan 68

Hasbi Hasan, Pemikiran dan Perkembangan Hukum Ekonomi Syariah di Dunia Islam Kontemporer, Gramata Publishing, Depok, 2011, h. 133.

Amran Suadi, Penyelesaian Sengketa Ekonomi Syariah Teori dan Praktik, Kencana Prenada Media Grup, Jakarta, 2017, h.14. 
pada Pasal 5 ayat (4) Undang-Undang Nomor 11 tahun 2008 yaitu ketentuan mengenai Informasi elektronik dan/atau Dokumen Elektronik sebagaimana dimaksud pada ayat (1) tidak berlaku untuk : Surat yang menurut Undang-Undang harus dibuat dalam bentuk tertulis dan Surat beserta dokumennya yang menurut Undang-Undang harus dibuat dalam bentuk akta notaril atau akta yang dibuat oleh pejabat pembuat akta.

\section{Perjanjian Elektronik Dalam Penyelesaian Sengketa Perdata}

Agar dapat diklasifikasikan dalam bentuk tertulis, ada beberapa cara yang dapat dilakukan, salah satunya yang lazim dilakukan adalah membuat suatu printout copy dari pesan yang masih berbentuk elektronik tersebut. Masalahnya hanya terletak pada tidak adanya satu peraturan hukum pun di Indonesia yang mengatur mengenai pengubahan dari bentuk data elektronik ke bentuk print out. Yang sudah ada aturannya justru kebalikannya yaitu dari bentuk nyata tertulis ke bentuk data elektronik, diatur dalam UU Dokumentasi Perusahaan pada Bab III Pengalihan bentuk Dokumen Perusahaan dan Legalisasi dari Pasal 12 sampai dengan Pasal 16. Kenapa hal ini menjadi penting dan dikemukakan, karena bila terjadi suatu perubahan bentuk dari suatu dokumen atau pesan, maka harus dapat dibuktikan bahwa perubahan bentuk tersebut tidak merubah isi dari dokumen/pesan yang diubah bentuknya itu. Konsekuensi hukumnya, kekuatan pembuktian dari bentuk ubahan tersebut harus sama sesuai kekuatan pembuktian dari bentuk asalnya.

Dalam persidangan, untuk dapat mempunyai kekuatan pembuktian yang penuh, maka selayaknya dalam mengajukan suatu fakta, pihak yang mengajukan fakta tersebut sudah selayaknya mengajukan alat bukti Surat Akta Otentik. Suatu Digital Signature sudah seharusnya mempunyai kekuatan pembuktian yang sama sebagaimana Surat Akta Otentik. Dalam hal e-commerce, tidak ada alat bukti lain yang dapat digunakan selain data elektronik atau digital yang ditransmisikan kedua belah pihak yang melakukan perdagangan. Adapun saksi, persangkaan, pengakuan dan sumpah, kesemuanya itu adalah tidak mungkin dapat diajukan sebagai alat bukti karena tidak bisa didapatkan dari suatu transaksi e-commerce. 
Bila dokumen elektronik tersebut mempunyai daya pembuktian yang sama dengan akta otentik, maka Undang-Undang Jabatan Notaris Nomor 30 Tahun 2004 haruslah direvisi, karena pada Pasal 1 ayat (7) akta notaris adalah akta otentik yang dibuat oleh atau di hadapan Notaris menurut bentuk dan tata cara yang di tetapkan dalam UndangUndang ini. Kekuatan pembuktian dari dokumen elektronik tersebut hanyalah akta dibawah tangan, dimana bentuk akta di bawah tangan dibuat dalam bentuk yang tanpa perantara atau tidak perantara atau tidak dihadapan pejabat umum yang berwenang, Mempunyai kekuatan pembuktian sepanjang para pihak mengakuinya atau tidak ada penyangkalan dari salah satu pihak. Jika salah satu pihak tidak mengakuinya, beban pembuktian diserahkan kepada pihak yang menyangkal akta tersebut, dan penilaian penyangkalan atas bukti tersebut diserahkan kepada hakim.

Jenis-jenis alat bukti di atas tidak jauh berbeda dengan alat bukti dalam hukum acara perdata yang diatur dalam Pasal 1866 Kitab Undang-Undang Hukum Perdata (KUHPerdata) jo Pasal 164 H.I.R/284 R.Bg akan tetapi dalam bunyi pasal tersebut tidak menyinggung tentang alat bukti elektronik. Namun, dalam alat bukti materil menyinggung alat bukti elektronik tapi tidak secara khususnya menyebut tentang dokumen elektronik. Dokumen elektronik diatur dalam Undang-Undang No. 11 Tahun 2008 Tentang Informasi Dan Transaksi Elektronik. Di dalam undang-undang tersebut dokumen elektronik beserta hasil cetaknya sah sebagai alat bukti dalam hukum acara khususnya acara perdata Indonesia.

\section{Penyelesaian Sengketa Online}

Proses arbitrase online khususnya dalam penyelesaian sengketa e-commerce yang dilakukan antara business to consumer(B2C), pilihan hukum yang digunakan adalah berdasarkan hukum nasional dari si pelaku bisnis, karena konsumen hanya memiliki pilihan menerima klausula baku arbitrase yang tersedia atau tidak melakukan $e$ commerce sama sekali (take it or leave it). Hal ini dipengaruhi hukum positif yang mengatur Internet di negara tersebut, sehingga di pengaturan mengenai $e$ commercemengikuti hukum yang mengatur tentang koneksi e-commerce dalam 
hubungan Internetnya. Dengan demikian proses arbitrase akan menggunakan pilihan hukum dimana media Internet yang menjalankan e-commerce berada.

Dalam Undang-undang Nomor 30 Tahun 1999 Pasal 4 ayat (3) yang dinyatakan bahwa : Dalam hal disepakati penyelesaian sengketa melalui arbitrase terjadi dalam bentuk pertukaran surat, maka pengiriman teleks, telegram, faksimili, e-mailatau dalam bentuk sarana komunikasi lainnya, wajib disertai dengan suatu catatan penerimaan oleh para pihak.

\section{Penutup}

Kesimpulan

a. Kekuatan pembuktian perjanjian elektronik pada akta otentik merupakan perluasan dari pembuktian hukum acara perdata di Indonesia sehingga seluruh transaksi elektronik dengan tanda tangan elektronik dapat dianggap sebagai akta, bahkan kekuatan pembuktiannya sama dengan akta otentik yang dibuat oleh pejabat yang berwenang. Jadi apabila kita hendak mengajukan suatu tanda tangan elektronik sebagai sesuatu yang di-attach pada suatu pesan untuk menjadikannya berkekuatan hukum yang sama dengan surat akta otentik, maka ada permasalahan yang harus dipecahkan. Pertama, aspek tertulis. Kedua, dibuat oleh atau di hadapan pejabat negara yang berwenang atau pegawai umum.

b. Penyelesaian sengketa perkara perdata yang diajukan para pihak dengan alat bukti perjanjian elektronik dapat dilakukan melalui proses litigasi dan non litigasi. Untuk dapat mempunyai kekuatan pembuktian yang penuh, maka selayaknya dalam mengajukan suatu fakta, pihak yang mengajukan fakta tersebut sudah selayaknya mengajukan alat bukti surat akta otentik. Suatu tanda tangan elektronik sudah seharusnya mempunyai kekuatan pembuktian yang sama sebagaimana surat akta otentik. 
Saran

a. Hukum Acara yang ada dan berlaku sekarang (hukum acara positif) dalam hal ini perlu ditinjau ulang untuk adanya kemungkinan dilakukannya suatu revisi, mengingat adanya kebutuhan yang mendesak ini. Masalah perjanjian elektronik sudah ada di depan mata dan adanya kemungkinan munculnya suatu kasus perselisihan/dispute. Yang perlu dilakukan dalam waktu singkat adalah memberikan suatu pemahaman kepada seluruh masyarakat khususnya kepada para pelaku hukum mengenai permasalahan pembuktian yang mungkin timbul tersebut dan revisi hukum acara positif sebagai tujuan jangka panjang tentu saja membutuhkan waktu yang tidak singkat karena membutuhkan perumusan terlebih dulu, belum termasuk tahapan pembentukan undang-undang di badan legislatif.

b. Dalam hal perjanjian elektronik, tidak ada alat bukti lain yang dapat digunakan selain data elektronik atau digital yang ditransmisikan kedua belah pihak, maka didalam menyelesaikan sengketa di pengadilan, Hakim dituntut untuk berani melakukan terobosan hukum, karena dia yang paling berkuasa dalam memutuskan suatu perkara dan area Hakim juga yang dapat memberi suatu vonnis van de rechter, yang tidak langsung dapat didasarkan atas suatu peraturan hukum tertulis atau tidak tertulis.

\section{DAFTAR PUSTAKA}

Buku

Abdul Halim Barkatullah dan Teguh Prasetyo, Bisnis E-Commerce, Pustaka Pelajar, Yogyakarta, 2005, h. 110.

Abdulkadir Muhammad, 2010, Hukum Perdata Indonesia, Bandung, Citra Aditya Bakti, h. 290.

Amran Suadi, Penyelesaian Sengketa Ekonomi Syariah Teori dan Praktik, Kencana Prenada Media Grup, Jakarta, 2017, h.14.

Bahtiar Effendi, Masdari Tasmin, dan A Chodari, Surat Gugat dan Hukum Pembuktian Dalam Perkara Perdata, Citra Aditya Bakti, Bandung, 1999, h. 50. 
Bambang Sunggono, Metodologi Penelitian Hukum, Raja Grafindo Persada, Jakarta, 2009 , h. 38.

Dewi Nurul Mustjtari, Penyelesaian Sengketa dalam Praktik Perbankan Syariah, Parama Publishing, Yogyakarta, 2012, h. 220.

Hasbi Hasan, Pemikiran dan Perkembangan Hukum Ekonomi Syariah di Dunia Islam Kontemporer, Gramata Publishing, Depok, 2011, h. 133.

Huala Adolf, Hukum Perdagangan Internasional, Raja Grafindo Persada, Jakarta, 2006, h. 168.

Johny Ibrahim, Teori dan Metodologi Penelitian Hukum Normatif, Bayumedia Publishing, Malang, 2006, h. 294.

Julian Ding, E-Commerce: Law \& Practice, Malaysia: Sweet \& Maxwell, Asia, 1999, h. 25.

M Yahya Harahap, Hukum Acara Perdata Tentang Gugatan, Persidangan, Penyitaan, Pembuktian, dan Putusan Pengadilan, Sinar Grafika, Jakarta, 2017, h. 637.

Priyatna Abdurrasyid, Arbitrase \& Alternatif Penyelesaian Sengketa Suatu Pengantar, Fikahati Aneska, Jakarta, 2002, h.109.

R Setiawan, Pokok-Pokok Hukum Perikatan, Bina Cipta, Bandung, 1999, h. 13.

Ronny Hanitjo Soemitro, Metodologi Penelitian Hukum dan Jurimetri, Ghalia Indonesia, Jakarta, 1990, h. 106.

Salim HS, Hukum Kontrak: Teori dan Teknik Penyusunan Kontrak, Sinar Grafika, Jakarta, h. 61.

Soerjono Soekanto dan Sri Mamudji, Penelitian Hukum Normatif (Suatu Tinjauan Singkat), Rajawali Pers, Jakarta, 2011, h. 13.

Subekti, Aneka Perjanjian, Intermasa, Bandung, 1995, h. 1.

Subekti, Hukum Pembuktian, Balai Pustaka, Jakarta, 2015, h. 7.

Sudikno Mertokusumo, Hukum Acara Perdata Indonesia, Cahaya Atma Pustaka, Yogyakarta, 2013, h. 28.

Sugiyono, Metode Penelitian Kuantitatif, Kualitatif, dan R\&B, Alfabeta, Bandung, 2009, h. 29. 
Zhou, K., Taigang $L_{\text {th }}$ dan Lifeng, Z., Industry 4.0: Towards future industrial opportunities and challenges, 12 International Conference on Fuzzy System, USA, 2015, h. 1.

Undang-Undang

Undang-Undang Dasar Negara Republik Indonesia Tahun 1945.

Hir (Het Hirziene Indonesisch Reglement) atau Reglement Indonesia, S. 1848 Nomor 16 jo. S. 1941 No. 44.

Rv. (Reglement op de Burgerlijke Rechtvordering) S. 1847 No. 52 jo. S. 1849 No. 63.

Rbg. (Rechtsreglement Buitengewesten) dan Reglement Daerah Seberang, S. 1927 Nomor 22.

Kitab Undang-Undang Hukum Perdata (Burgerlijk Wetboek): dengan tambahan UndangUndang Pokok Agraria dan Undang-Undang Perkawinan, diterjemahkan oleh R. Subekti dan R. Tjitrosubidio, 2008, Pradnya Paramita Jakarta.

Undang-Undang Nomor 20 Tahun 1947 Tentang Banding untuk daerah Jawa dan Madura.

Undang-Undang Nomor 8 Tahun 1997 Tentang Dokumen Perusahaan (Lembaran Negara Republik Indonesia Tahun 1997 Nomor 18 - Tambahan Lembaran Negara Republik Indonesia Tahun 1997 Nomor 3647).

Undang-Undang Nomor 30 Tahun 1999 Tentang Arbitrase dan Alternatif Penyelesian Sengketa (Lembaran Negara Republik Indonesia Tahun 1999 Nomor 138 - Tambahan Lembaran Negara Republik Indonesia Tahun 1999 Nomor 3872).

Undang-Undang Nomor 08 Tahun 1999 Tentang Perlindungan Konsumen (Lembaran Negara Republik Indonesia Tahun 1999 Nomor 22 - Tambahan Lembaran Negara Republik Indonesia Tahun 1999 Nomor 3821).

Undang-Undang Nomor 30 Tahun 2004 Tentang Jabatan Notaris (Lembaran Negara Republik Indonesia Tahun 2004 Nomor 117 - Tambahan Lembaran Negara Republik Indonesia, Tahun 2004 Nomor 4432).

Undang-Undang Nomor 2 Tahun 1986 jo. Undang-Undang Nomor 8 Tahun 2004 Tentang Peradilan Umum (Lembaran Negara Republik Indonesia Tahun 2004 Nomor 43 - Tambahan Lembaran Negara Republik Indonesia Tahun 2004 Nomor 4379). 
Undang-Undang Nomor 11 Tahun 2008 sebagaimana telah dirubah dengan UndangUndang Nomor 19 Tahun 2016 Tentang Informasi dan Transaksi Elektronik (Lembaran Negara Republik Indonesia Tahun 2016 Nomor 251 - Tambahan Lembaran Negara Republik Indonesia Tahun 2016 Nomor 5952).

Undang-Undang Nomor 48 Tahun 2009 Tentang Kekuasaan Kehakiman (Lembaran Negara Republik Indonesia Tahun 2009 Nomor 157 - Tambahan Lembaran Negara Republik Indonesia Tahun 2009 Nomor 5076).

Undang-Undang Nomor 14 Tahun 1985 jo. Undang-Undang Nomor 5 Tahun 2004 jo. Undang-Undang Nomor 3 Tahun 2009 Tentang Mahkamah Agung (Lembaran Negara Republik Indonesia Tahun 2009 Nomor 3 - Tambahan Lembaran Negara Republik Indonesia Tahun 2009 Nomor 4958).

\section{Sumber Internet}

http://www.vdinachrichten.com/Technik-Gesselschaft/Industrie-40-Mit-Internet-DingeWeg-4-industriellen-Revolution, tanggal kunjung 29 juli 2019, (15.00).

https://www.cnbcindonesia.com/news/20180816114214-4-28906/revolusi industri-40jokowi-indonesia-harus-beradaptasi, tanggal kunjung 29 Juli 2019, (14.00).

https://www.mahkamahagung.go.id/id/artikel/3048/eksistensi-dokumen elektronik-dipersidangan-perdata, tanggal kunjung 31 Juli 2019, (16.00). 